\title{
Interests groups in Parliament: Exploring MPs' interest affiliations (2000-2011)
}

\author{
Roy Gava*, Frédéric Varone*, André Mach**, Steven Eichenberger**, \\ Julien Christe*** and Corinne ChaO-Blanco*** \\ *Department of Political Science and International Relations, University of \\ Geneva \\ **Institute of Political, Historical and International Studies, University of \\ Lausanne \\ $* * *$ No affiliation
}

\begin{abstract}
This research note presents an innovative dataset of Swiss MPs' interest ties between 2000-2011. The longitudinal analysis shows that the average number of interest ties per MP has more than doubled: from 3.5 in 2000 to 7.6 in 2011. Since the mid-2000s, public interest groups have accounted for approximately one out of two ties between MPs and interest groups, showing the strongest increase during the period. However, when looking at the most present individual groups, important business groups dominate and appear well connected with the governmental parties of the political right. Finally, interest groups are also able to forge themselves a strategic presence within the parliamentary committees that are the most relevant for their policy issues. Next research steps include the assessment of the (un)biased access of interest groups to the parliamentary venue and their policy influence.
\end{abstract}

\section{Introduction $^{1}$}

This extended research note investigates how interest groups develop privileged relationships with members of the Swiss parliament (MPs). A new dataset, which is based on the official register of MPs' interest affiliations, provides an overview of the evolution of the type, policy domains and partisan linkages of interest groups across three legislatures (2000-2011). Beyond the descriptive analysis of about 20'000 dyads between MPs and groups, this research note discusses the potential of the dataset to investigate the (un)biased mobilization, institutional access and policy influence of interest groups in the Swiss parliament.

Apart from political science studies (Bailer 2011; Bruderer 2005; Giger and Klüver 2016; Lüthi, Meyer and Hirter 1991; Schwarz and Linder, 2007), MPs' ties with private interests have been put lately under increasing scrutiny in Switzerland. Journalists refer to this issue

\footnotetext{
${ }^{1}$ This research note is part of a research project funded by the Swiss National Science Foundation (100018_149689-1), directed by Frédéric Varone and André Mach, and entitled "Lobbying, Litigation and Direct Democracy: Comparing Advocacy Strategies of Interest Groups in Switzerland and California". The authors acknowledge the Faculty of Social and Political Sciences of the University of Lausanne for its financial support. They are also indebted to Frank Baumgartner, Pascal Sciarini, Manuel Fischer, Nathalie Giger and two anonymous reviewers for helpful comments.
} 
regularly, both by looking at the general phenomenon ${ }^{2}$ and by spotting on specific cases. ${ }^{3}$ Economists have investigated MPs' ties with firms (Péclat and Puddu 2015; Puddu and Péclat 2015). Nevertheless, none of these initiatives have systematically mapped the ties of MPs with interest groups in a way that would allow longitudinal and cross-national studies.

This research note is structured as follows. First, we introduce the data collection procedure. Then we underline why it is theoretically relevant to investigate the ties between interest groups and MPs in Switzerland and we formulate four theoretical expectations. The empirical findings show how the dyads formed by the relations between interest groups and MPs evolve over time, across various types of groups and policy domains. We also shed new light on the links established by groups with political parties and committees in Parliament. The concluding section shows how this data on MPs' interest affiliations paves the way to tackle innovative research questions.

\section{Dataset on interest groups in Parliament}

To define an organization as an interest group, we refer to the three cumulative conditions proposed by Jordan et al. (2004) and Beyers et al. (2008: 1106), namely: (1) interest groups are organizations with individual members, and neither private firms nor lose movements or even ephemeral waves of public opinion; (2) interest groups attempt to influence policymaking processes and outputs by engaging in policy advocacy; (3) interest groups have no office-seeking goal. They do not compete for election and are not formally part of the government. Nevertheless, interest groups try to influence elected politicians, bureaucrats or judges, through institutionalized or informal interactions.

Swiss MPs have been required since 1985 to declare all their mandates (e.g. executive boards seats) with companies, foundations, committees, federal agencies and interest groups (see Art. 11 of the Parliament Act). The Parliamentary Services collect this information and publishes yearly an 'Official register of MP's interests' (from now on 'the register'). This documentary source is available online, ${ }^{4}$ with data going back to 1985. However, an 'important' change took place with the introduction of the 2002 Parliament Act. Up to then, and according to the previous law regulating parliamentary activities, MPs were only required to disclose their 'important' mandates (Commission des institutions politiques du Conseil national 2001: 3360-3361). The new rules stipulate that all mandates should be declared, regardless of their 'importance'. The first version of the register under these stricter disclosure rules was published in 2004.

We assume that most MPs declare all their interest affiliations in order to fulfill their legal duties. However, we acknowledge that some MPs (deliberately?) forgot some of their mandates. For example, MP Schneider-Ammann, who is nowadays member of the Government, was put under the spotlight by the media when journalists revealed that he

\footnotetext{
${ }^{2}$ See for example the Lobbywatch project (http://www.lobbywatch.ch), the NZZ's infographics (http://www.nzz.ch/ spezial/lobbying-im-bundeshaus), the mapping by Martin Grandjean (http://www.martingrandjean.ch), as well as the recent wave of newspaper stories in both sides of the Röstigraben (Bellini 2014; Buchs 2014; Kohli 2014; Nicolussi 2014a, 2014b; Zaugg 2011).

${ }^{3}$ Emblematic and recent examples include the revelation of parliamentary interventions being written by lobbying firms (e.g. the highly mediatized scandal of a parliamentary intervention introduced by MP Christa Markwalder that was written by the private PR-Firm Burson-Marsteller on behalf of activists from Kazakhstan) or the lobbying by the pharmaceutical industry, health insurances companies and medical associations on the new Federal Act on Medicinal Products and Medical Devices (Bellini, 2014).

${ }^{4}$ See http://biblio.parlament.ch/e-docs/357435.pdf (last access 30 April 2015).
} 
had failed to declare some of his own offshore firms (Zaugg 2011; see also Péclat and Puddu 2015). Today, MPs are probably less tempted to omit declaring a mandate, since they fear the political risk of being publicly named and shamed.

To collect data on interest groups, which have direct ties to MPs, we rely on the annual versions of the register for the period 2000-2011. ${ }^{5}$ The database encompasses the interest declarations submitted by the 429 MPs that held a seat in the National or State Councils at any point during three legislative terms (i.e. 1999-2003, 2003-2007, 2007-2011). The year-based 'raw' inventory of the register for the twelve years covered yields almost 20'000 dyads between MPs and organizations. Following correction for spelling variances and language differences, a total of 3'793 organizations was identified. Note that for the purposes of this research note, and when appropriate, multiple cantonal or regional sections of the same organizations were manually aggregated into a single entity. For example, the different cantonal, regional and national units of an organization such as the Swiss Automobile Club were regrouped under a single organization. A similar procedure was applied to firms, where subsidiaries were regrouped under parent companies where applicable. Following this 'cleaning', the total number of 'unique' organizations identified was further reduced to 3'227. Analyses in this paper are based on the dyads representing interest ties, which are formed between MPs and the organizations that they have declared.

While the dataset is currently limited to Switzerland, it was conceived with a comparative perspective. In order to assess the type of organizations to which MPs were affiliated, as well as the policy domain in which each declared organization was primarily active, two widely used international coding schemes were manually applied.

First, distinct organization types were captured by means of the typology of the Interarena project. ${ }^{6}$ The Interarena codebook is a well-tested instrument to capture the diversity of interest groups' population (Binderkrantz et al. 2015). Relying on this classification scheme, we capture organizations' diversity by means of seven categories of groups. (1) Business groups and (2) unions are the 'usual suspects' that first come to mind when assessing associations' political influence. Privileged by analyses of neo-corporatism, these are by far the groups that have been studied the most in Switzerland (Mach 2014: 414). (3) Professional groups are formed by individuals who share the same occupation. Representatives of liberal professions, such as doctors (e.g. Swiss Medical Association) or lawyers, are typical examples, but other organizations focused on professional training or certification are also present. MPs' affiliations with universities and research institutions are also considered professional under this category (e.g. Swiss Forum for Migration and Population Studies). (4) Identity groups primarily seek benefits for their own members or restrained constituencies. Examples include groups representing women, tenants, drivers (e.g. Swiss Automobile Club) or minorities (e.g. Organization of the Swiss Abroad). (5) Public interest groups are formed by individuals who focus on the attainment and

\footnotetext{
${ }^{5}$ In addition to this official register of interest affiliations, it should be noted that each MP can also deliver two access badges to the "Wandelhalle im Bundeshaus" that are valid for one year (see the official "List of accreditations", http://www.parlament.ch/d/organe-mitglieder/nationalrat/Documents/zutrittsberechtigte-nr.pdf, last access 30 April 2015). Among the accredited persons, many are professional lobbyists working for private firms, interest groups or "Public Affairs" consultancies. Lobbyists may also benefit from one-day passes. Last but not least, previous MPs who retired from their political mandate can still enter the "Bundeshaus" and thus operate as very well informed and connected lobbyists. These lobbyists should ideally also be captured to grasp the full picture of how organized interests engage in policy advocacy in the Parliament.

${ }^{6}$ See http://interarena.dk/
} 
protection of common goods. In contrast to identity groups, their aims go beyond their members' interests. Examples of this category include environmental groups or humanitarian organizations, as well as family foundations. Leisure groups (6) refer to associations in which members come together on the basis of shared hobbies, artistic or sport-related interests. Examples include Scout groups, orchestras' support associations and Swiss Olympic. Finally, religious groups (7) include spiritual organizations, such as churches or other associations focused on the promotion or support of religious communities. The Swiss Evangelical Alliance or abbeys' support associations are among them.

Second, the main domain of activity for each organization was coded on the basis of the main categories of the Comparative Agendas Project $(C A P){ }^{7}$ This classification of policy domains has been widely used in comparative policy and politics, in order to assess the relative distribution to issues of a wide range of phenomena, from legislative production to media attention (Green-Pedersen and Walgrave 2014). The adoption of such widespread categories in terms of interest groups and policy domains opens the way to future analyses across countries and datasets. For example, studies could rely on parliamentary activities datasets to assess whether ties with interest groups active in specific policy domains have, an impact on the number of parliamentary interventions (e.g. questions, interpellations, motions) introduced by MPs in that policy domain.

Following supervised training, the authors of this research note classified organizations on the basis of the Interarena and the CAP codebooks. Under both coding schemes, categories are mutually exclusive. In addition to the information provided by the register, the coders relied on the organizations' websites and the registry of commerce to identify the type and main domain of activity for each organization. ${ }^{8}$

\section{Theoretical expectations about MPs: groups ties}

Switzerland is well known for the central importance of interest groups, especially economic organizations (such as business associations or trade unions), at the different stages of the policy-making process (Katzenstein, 1985; Kriesi 1980; Mach 2014). In the context of an underdeveloped central state and weak national political parties, Swiss interest groups, because of their various resources (financial, staff, membership and institutional recognition by public authorities) and their early organization at the national level, are generally considered as major and influential political actors. However, previous studies (David et al. 2010; Giger and Klüver 2016; Häusermann, Mach and Papadopoulos, 2004; Sciarini, Fischer and Traber 2015) do not offer an encompassing view of the diversity and influence of interest groups in Swiss politics and policy-making. This is all the more surprising since the role and strategies of interest groups have changed considerably during the last twenty years. Interactions between interest groups and public authorities seem to have evolved from neo-corporatist arrangements toward more pluralist and competitive lobbying relations. In particular, interest groups are more actively

\footnotetext{
${ }^{7}$ See http://www.comparativeagendas.net

${ }^{8}$ Intercoder agreement tests and meetings were organized regularly before and throughout the coding process with the two coders. During the coding process ( 9 tests), the average Krippendorff's alpha scores were 0.75 for CAP topics and 0.71 for Interarena's categories (30 organizations per test). Since the first exploratory analyses, members of the research team propose coding revisions through a centralized procedure.
} 
targeting the Parliament than in the past (Armingeon 2011, Mach 2015, Sciarini, Fischer and Traber 2015).

For decades, the conventional wisdom was that the core compromises of legislation are negotiated during the pre-parliamentary phase. When a bill reaches the Parliament, political deals among policy stakeholders have already been settled, and MPs introduce very few changes in the final legislative acts (Zehnder 1988). In accordance with this view, MPs have few incentives to review and alter political agreements struck in the preparliamentary phase, since this may open the way to an optional referendum.

It is not surprising that research on interest groups has privileged the administrative arena. For instance, scholars have focused on seats held by interest groups in 'extraparliamentary committees', which are in charge of preparing legislation or regulations, and on the consultation procedures organized by the federal administration on bill drafts. Notably, policy actors themselves have systematically reported that the pre-parliamentary phase was by far the most important in the Swiss decision-making process (see the seminal study by Kriesi (1980: 589)).

To update Kriesi's (1980) study on policy-making in the early 1970s, Sciarini and his team have analyzed the eleven most important decision-making processes of the early 2000s. Their findings show that the parliamentary phase has partly caught up with the preparliamentary phase: "while in the early 1970s the preparatory phase was overall seen as the most important phase by almost 80 percent of the respondents, this share has dropped to 60 percent. [...] The importance of both expert committees and consultation procedure has halved" (Sciarini, Fischer and Traber 2015: 34). Representatives of state agencies, political parties and interest groups agree on the increasing importance of the parliamentary stage for policy outputs (Sciarini, Fischer and Traber 2015: 36).

In Switzerland, several factors contributed to the re-valorization of the Parliament as an institutional venue, and presumably as a strategic target for policy advocates. First, the rising role of Parliament is partly due to the institutional reform of 1992, based on the replacement of ad hoc committees by permanent, specialized committees (Jegher 1999; Lüthi 1997; Pilotti 2012). MPs have become increasingly specialized and competent in some policy fields and might thus exchange information and expertise with interest groups more actively. Second, Parliament increased the remunerations of MPs in 1991 and 2002, diminishing thus the traditional 'militia character' of the Swiss Parliament, which was seen previously as "composed of amateurs who combine their professional activities with their parliamentary duties" (Kriesi 2001: 60). The growing professionalization of MPs has paralleled the growing professionalization of advocacy. Increasingly, sector-specific interest groups approach MPs directly, while firms specialized in lobbying or 'public affairs' are more visible. ${ }^{9}$ Third, repeated studies on the rates of amendments made to government proposals in the 1990s and early 2000s concluded that the law-making capacity of the Swiss parliament has become stronger (Jegher and Lanfranchi, 1996; Jegher and Linder 1998; Schwarz, Bächtiger and and Lutz 2011).

If a 're-parliamentarization' phenomenon is at work in Switzerland, then interest groups could be expected to invest more intensively in this venue, complementing their advocacy activities in the pre-parliamentary phase. Direct access to MPs is a valuable insider strategy' in groups' action repertoire (Rommetvedt, Thesen, Christiansen and Norgaard, 2012). As gaining access to MPs is probably becoming more important for interest groups aiming to influence policy agendas and outputs, we expect that the number of ties between

\footnotetext{
${ }^{9}$ See for instance the recently created Society of Public Affairs (http://www.public-affairs.ch).
} 
MPs and interest groups increases over time. At the same time, the research of Jentges et al. (2013: 36) on Switzerland suggests a continuous growth of interest groups' population. As the stock of groups increases, they may be more likely to be represented among MPs' ties.

Furthermore, two related factors lead us to expect an increase in the share of public interest groups over time. First, a 'pluralization' of interest groups is observed in various neo-corporatist countries (Pedersen et al. 2014). Based on the data collected by Jentges et al. (2013), we expect a similar diversification of the interest groups' population in Switzerland. Second, the literature on population ecology (see Lowery et al. 2015 for an overview) has pointed out that when public interest groups are in competition for members, as the size of the overall groups' population increases, then they are active politically and mobilize to attract new members and secure their organizational survival. Having a strong link with an MP thus represents an attractive asset to showcase that may additionally contribute to the organizational wealth of public interest groups.

To be influential in the parliamentary venue, interest groups have to behave strategically when approaching MPs. On the one hand, interest groups will probably get in touch with MPs according to their partisan affiliation and policy preferences. We expect that interest groups hold ties with MPs belonging to a political party whose political priorities are close to the group's main objectives. On the other hand, an interest group has also a strong incentive to develop privileged relationships with members of the specialized committee dealing with the policy issues that are relevant for the group. Swiss scholars agree that parliamentary committees have become increasingly important (Jegher 1999; Lüthi 1997; Pilotti 2012; Sciarini 2014). Ties with MPs may thus provide interest groups with a strategic presence within these specialized committees. Our last expectation reads as follows: Interest groups entertain privileged ties with MPs belonging to the parliamentary committee that focus on the group's domain of activity. The following sections present first empirical evidence of these four theoretical expectations.

\subsection{Increasing ties over time}

The stricter declaration provisions included in the new Parliamentary Act (i.e. mandatory self-declaration of all ties with organizations) came into effect with the 2004 version of the register. Nevertheless, the number of organizations to which MPs declared to have ties with was already in an ascendant trend before. Between the first and the last annual register covered in the dataset, the average number of interest ties per MP more than doubled: from 3.5 in 2000 to 7.6 in 2011. The peak was observed in 2007, when MPs declared in average almost eight organizations. Behind these values, there is considerable heterogeneity across individual MPs. For example, and for the entire period 2000-2011, 14 MPs did not declare any kind of organization in the register. At the other extreme, the ranking of interest affiliations was dominated by a single MP who declared ties with 51 different organizations.

While a thorough analysis at the individual level would deserve a paper in itself (see for example Péclat and Puddu (2015)), the dyads formed by the relations between MPs and organizations are privileged in this research note. Broadly speaking, the register allows identifying MPs' ties with three main types of organizations. First, MPs may declare mandates within interest groups as defined above. Second, MPs may be related to private firms. Third, in parallel to their role in Parliament, MPs may ensure functions in staterelated organizations. For the three legislative terms under study, the 3'227 organizations 
identified were distributed as follows: 1'537 (48\%) interest groups, 1'245 (39\%) companies and $445(14 \%)$ state-related organizations.

Many of the controversies surrounding MPs' interest ties that have reached headlines in the past have focused on MPs' relations with private firms. While MPs sitting simultaneously in the board of multinationals and the relevant parliamentary committee are likely to attract the general public's attention, a systematic look at the registry reveals that the type of companies linked to MPs is extremely diverse, both in size and economic orientation. The listed firms by MPs range from self-employed, family businesses (e.g. consulting, agricultural production) or cooperatives (e.g. Migros) to multinational companies (e.g. big banks, the pharmaceutical industry).

Being high-profile politicians with generally a well-established political career, federal MPs are particularly prone to entertain ties with state-related organizations. This phenomenon may be accentuated by previous or simultaneous mandates as representatives at the cantonal or communal level. Among these organizations, whose primary activity is the provision of public services, we find institutions such as the Swiss National Bank, as well as (full or partial) public-owned companies (e.g. such as those active in public transportation and public utilities).

Figure 1 shows MPs' ties in accordance to the three types of organizations sketched above. Some notable changes are observable throughout the decade under investigation. First, interest groups display a clear reinforcement in the number of ties with MPs, both in absolute and relative terms. While at the beginning of the period under study the presence of groups was roughly comparable to that of firms, the number of MP-group ties increased notably over time. This is particularly remarkable since the beginning of the 2003-2007 legislative term, from which point groups systematically accounted for over one out of two interest ties. In 2011, the last year on the dataset, groups accounted for $62 \%$ of the declared ties, up from $38 \%$ at the beginning of the decade. Second, when contrasted to both companies and state organizations, ties between groups and MPs stand out due to

Figure 1: MPs' interest ties with types of organizations (2000-2011)

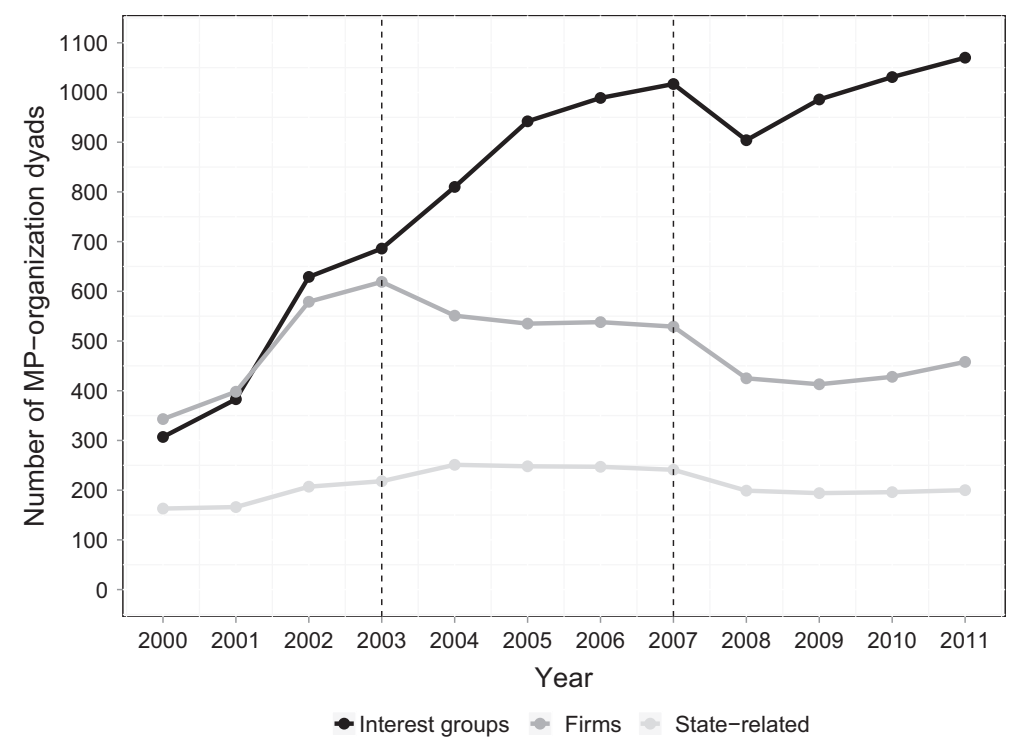


their growth not only across, but also within legislative periods (separated by dotted lines). Third, hand in hand with the marked increase of interest groups, a relative decline of MPs' ties with firms is observable. Between 2000 and 2011, the share of firms among MPs' interest ties decreased from $42 \%$ to $27 \%$. Fourth, while the proportion of links with groups and firms fluctuates considerably over time, the share of ties with state organizations shows less volatility.

The years previous to the introduction of the new Parliament Act requiring MPs to disclose not just the 'important' interest ties may have pushed MPs to declare previously existing interest affiliations. While the bill was adopted in 2002 and the requirement entered into force only in 2004, the rule requiring the disclosure of all interest affiliations was officially under the consideration of Parliament since 2001. Nevertheless, this institutional change is unable to account for the continuous growth in the number of MPs' ties with interest group ties after 2004 and within the following legislative periods. Moreover, it does not inform on the increase of interest groups ties and the stagnation of firms ties since 2004 .

Overall, this first assessment confirms our first theoretical expectation. These findings suggest a strong reinforcement of the presence of interest groups in Parliament by means of ties with MPs.

\subsection{Distribution across group types}

The growing presence of interest groups among MP's interest affiliations calls for closer examination.

Leaving behind firms and state-related organizations, Figure 2 offers a disaggregated view of the interest groups declared by MPs. ${ }^{10}$ First, when considered together, public interest, business and professional groups concentrated continuously around $85 \%$ of the total number of MPs' ties with groups throughout the period. Second, the ranking of group types has remained largely stable throughout the decade, with no significant changes. Third, during a period in which links between MPs and groups sharply increased, public interest groups reinforced their first position. Since the mid-2000s, public interest groups accounted for approximately one out of two ties between MPs and groups. Fourth, and despite a noticeable decline (in relative, but not in absolute terms) since the 2003-2007 legislative term, business groups dwarfed trade unions. During most of the period, MPs' ties with business groups were roughly ten times those of unions.

The rise of interest groups captured by means of the register is in large part linked to the increasing formal ties between MPs and public interest groups, as put forward in our second expectation. The most represented types of public interest groups include groups focusing on humanitarian issues, environment and animal welfare, heritage and history and ideological and political issues. This evolution is related to the above average creation of public interest groups since the 1970s, and, more precisely, to their increased political mobilization and political access to the Parliament during the last 15 years.

\subsection{Distribution across parties and domains}

MPs' interest affiliations are scattered across entities: more than $80 \%$ of the 3'227 organizations identified held one single link with an MP. Less than $5 \%$ of the

\footnotetext{
${ }^{10}$ In Figure 2, the category "Other" includes Identity, Leisure and Religious groups.
} 
Figure 2: MPs' ties with types of interest groups (2000-2011, N=2’386)



organizations were declared by more than three MPs. An additional remarkable indication of the relative weight of interest groups within the registry arises when looking at the ranking of organizations in terms of number of connections with MPs. Among the top 20 organizations, we find 16 interest groups, three state-organizations and only a single firm.

By taking into consideration the number of ties with different MPs, Figure 3 offers an overview of the interest groups with the strongest presence in Parliament during 20002011. The respective political affiliation of these MPs is shown for the five parties most represented in Parliament, both for the right (the Swiss People's Party, SPP, the RadicalLiberals, RLP, and the Christian-Democrats, CDP) and the left (the Social Democrats, SDP, and the Green Party, GPS). Four of the five groups at the top share remarkable characteristics: they represent business interests while displaying an equitable distribution of ties across the three main 'bourgeois parties' (SPP, RLP and CDP). They also represent different but important economic sectors: real estate (Swiss Homeowners' Association), small and medium enterprises (Swiss Industry and Trade Association), agriculture (Swiss Farmers' Union) and energy production (Swiss Energy Forum). Nevertheless, the strong presence of business groups with noticeable ties with the governmental parties of the political right is not limited to the top of the ranking. The ranking is completed by other business groups (e.g. Economiesuisse, Action for a reasonable energy policy, Swiss Employers' Association) with an intense connection with these very same parties. This finding leads us to qualify the relative decline of business groups observed previously. When contrasted to the increasing number of ties of MPs with public interest groups, business groups in Parliament seemed to be losing weight. However, when looking at the number of ties with MPs held by individual organizations, business dominates and appears particularly well connected with the governmental parties with which it shares ideological affinities.

Two other contrasting types of groups are apparent from the ranking shown in Figure 3. The first contrast comes when looking at groups that are strongly linked to the 
Figure 3: MPs' ties with the 15 most frequent interest groups by political party (2000-2011)

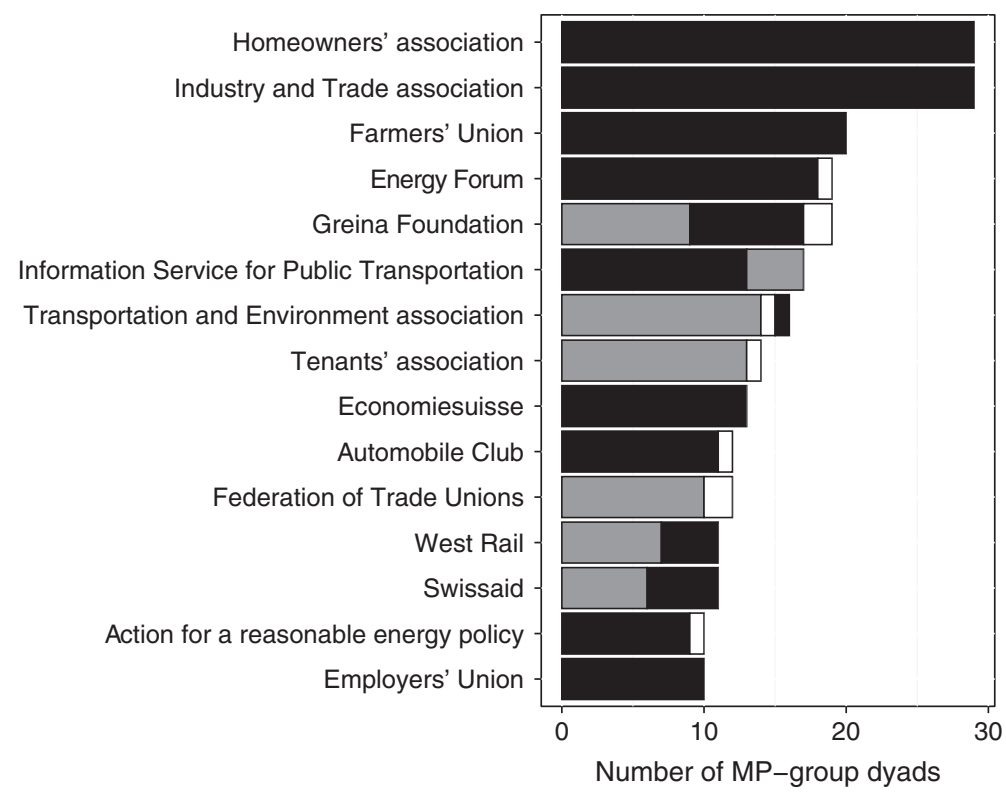

$\square$ Left (SDP, GPS) $\square$ Right (SPP, RLP, CDP) $\square$ Other parties

political left (SDP, GPS). These groups are active on different areas close to the traditional left's issue priorities, including transportation (Transportation and Environment Association), tenants and unions (Swiss Federation of Trade Unions). Last but not least, among these particularly well connected interest groups, there is a selected group that go beyond this left-right divide and entertains ties with MPs from a wide political spectrum. These are public interest groups, among which we find Greina Foundation (protection of alpine rivers) and Swissaid (humanitarian aid).

While limited to the most represented groups, these results show congruence between political parties and types of interest groups, in line with our third theoretical expectation. In Figure 4, we go one step further and investigate all the MPs-groups ties in terms of policy domains. Based on the CAP coding scheme, the heatmap shows the distribution of MPs' ties by policy domain within the main political parties (column percentages). In addition, policy domains on the $\mathrm{Y}$-axis are ordered in accordance to their relative weight across all parties. For example, 15\% of all the MP-group ties identified in Parliament are related to 'environment, energy and transportation'. As the relative dark color of the cell indicates, this policy domain is particularly important within the GPS, accounting for almost $30 \%$ of all the party's MP-group ties.

Thematically, groups are largely concentrated in a few CAP domains. 'Education, culture and sports', 'Health', 'Business and economics', as well as 'Environment, energy and transportation' account for the lion's share: almost $60 \%$ of the total ties.

Despite this relatively high concentration, some of the differences across parties are unsurprising for observers of Swiss politics and party agendas (Varone et al. 2014). Two observations provide additional evidence for corroborating our third expectation. First, partisan links between MPs and business associations evolves considerably as we move 
Figure 4: MPs' ties with interest groups by policy domain and political party (2000-2011, N=2'384)

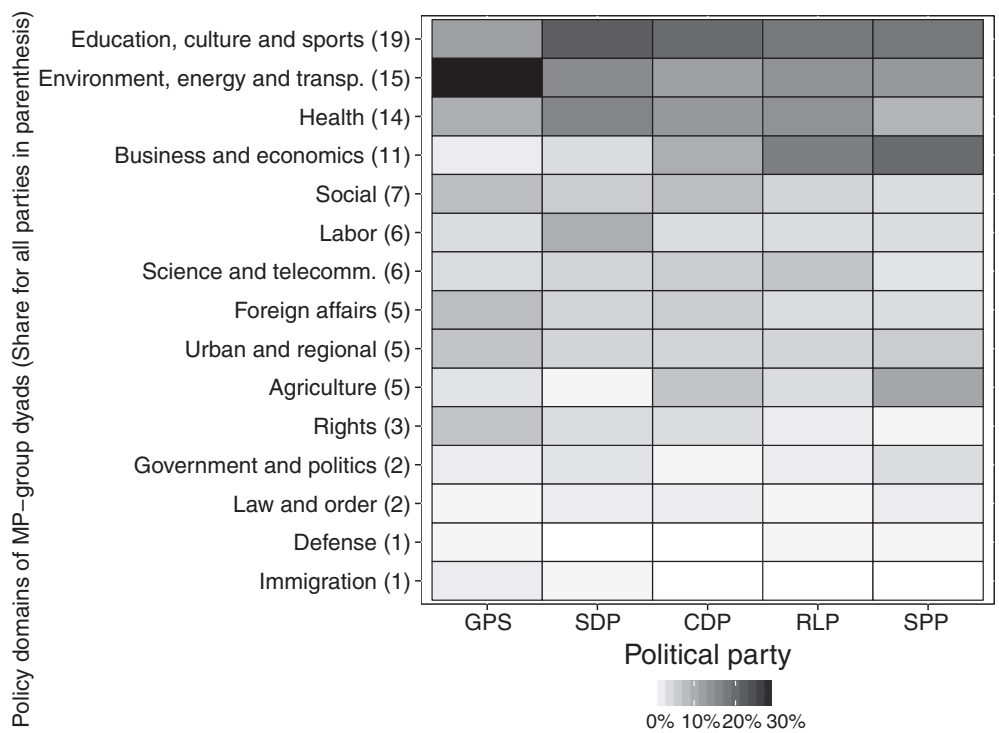

along the left-right axis. While this category is relatively weak within the GPS $(2 \%)$, it is among the most important for the SPP $(20 \%)$. Second, some indications of partisan issue ownership are observable in the data. Consider for instance the importance of 'Environment, energy and transportation' for the GPS (29\%), 'Labor' for the SDP (10\%) or 'Agriculture' for the SPP (11\%).

\subsection{Distribution across committees}

Finally, we turn to our fourth and last expectation by taking into consideration MPs' membership in parliamentary committees. In order to do so, we link MP-group ties to specialized committees on the basis of their respective policy domains. ${ }^{11}$ Figure 5 represents a two-way contingency table between committees (columns) and policy domains of interest groups (rows), attributing each tie to one specific policy domain and one or several committees $^{12}$. The cells display row percentages. The total of the row percentages exceeds $100 \%$. This is due to the fact that some MPs hold more than one committee seat simulatenously, or switch committees during their legislative careers. For this reason, one tie can most often be attributed to several committees.

According to our fourth expectation, we expect ties attributable to a specific policy domain to be concentrated within the committee dealing with policies falling into this particular domain. For instance, ties attributable to interest groups working in the transportation policy domain should appear more often in the Transportation Committee,

\footnotetext{
${ }^{11}$ Here we focus solely on the members of the National Council. Members of the Council of States each hold at least two committee seats simultaneously which considerably "dilutes" the concentration of ties in specific committees.

12 Note that the category "Environment, energy and transportation" from Figure 4 has been split into "Environment and energy" and "Transportation" in Figure 5 to account for the thematical organization of parliamentary committees.
} 
Figure 5: Association between topical focus of ties and parliamentary committees (2000-2011, $\mathrm{N}=1533)$

\begin{tabular}{|c|c|c|c|c|c|c|c|c|c|c|}
\hline & Legal Affairs & $\begin{array}{c}\text { Economic } \\
\text { Affairs and } \\
\text { Taxation } \\
\end{array}$ & $\begin{array}{l}\text { Environment, } \\
\text { Spatial } \\
\text { Planning and } \\
\text { Energy }\end{array}$ & $\begin{array}{c}\text { Political } \\
\text { Institutions }\end{array}$ & Defense & $\begin{array}{r}\text { Foreign } \\
\text { Affairs } \\
\end{array}$ & $\begin{array}{c}\text { Social } \\
\text { Security } \\
\text { and Health } \\
\end{array}$ & $\begin{array}{l}\text { Science, } \\
\text { Education } \\
\text { and Culture }\end{array}$ & $\begin{array}{c}\text { Transportation } \\
\text { and } \\
\text { Telecomm. }\end{array}$ & $\begin{array}{r}\text { National } \\
\text { Council }\end{array}$ \\
\hline Transportation & $22 \%$ & $8 \%$ & $17 \%$ & $14 \%$ & $19 \%$ & $8 \%$ & $17 \%$ & $14 \%$ & $38 \%$ & 78 \\
\hline Science and telecommunications & $16 \%$ & $18 \%$ & $11 \%$ & $22 \%$ & $12 \%$ & $19 \%$ & $11 \%$ & $37 \%$ & $16 \%$ & 83 \\
\hline Education, culture and sports & $23 \%$ & $7 \%$ & $8 \%$ & $15 \%$ & $20 \%$ & $22 \%$ & $13 \%$ & $24 \%$ & $12 \%$ & 298 \\
\hline Health & $21 \%$ & $6 \%$ & $8 \%$ & $19 \%$ & $15 \%$ & $12 \%$ & $37 \%$ & $20 \%$ & $7 \%$ & 189 \\
\hline Labor & $15 \%$ & $12 \%$ & $9 \%$ & $17 \%$ & $16 \%$ & $14 \%$ & $16 \%$ & $31 \%$ & $14 \%$ & 100 \\
\hline Social & $18 \%$ & $8 \%$ & $6 \%$ & $21 \%$ & $25 \%$ & $16 \%$ & $25 \%$ & $22 \%$ & $8 \%$ & 106 \\
\hline Foreign affairs & $35 \%$ & $8 \%$ & $7 \%$ & $13 \%$ & $27 \%$ & $42 \%$ & $9 \%$ & $18 \%$ & $11 \%$ & 88 \\
\hline Defence & $13 \%$ & $6 \%$ & $6 \%$ & $25 \%$ & $38 \%$ & $6 \%$ & $25 \%$ & $0 \%$ & $6 \%$ & 16 \\
\hline Immigration & $25 \%$ & $17 \%$ & $25 \%$ & $42 \%$ & $33 \%$ & $8 \%$ & $8 \%$ & $0 \%$ & $0 \%$ & 12 \\
\hline Rights & $12 \%$ & $11 \%$ & $16 \%$ & $16 \%$ & $12 \%$ & $9 \%$ & $18 \%$ & $18 \%$ & $9 \%$ & 57 \\
\hline Government and politics & $22 \%$ & $7 \%$ & $10 \%$ & $28 \%$ & $13 \%$ & $7 \%$ & $10 \%$ & $17 \%$ & $20 \%$ & 69 \\
\hline Environment, energy \& public lands & $24 \%$ & $5 \%$ & $32 \%$ & $16 \%$ & $18 \%$ & $16 \%$ & $14 \%$ & $19 \%$ & $22 \%$ & 152 \\
\hline Business \& economics & $12 \%$ & $26 \%$ & $20 \%$ & $8 \%$ & $15 \%$ & $11 \%$ & $7 \%$ & $19 \%$ & $15 \%$ & 184 \\
\hline Agriculture & $4 \%$ & $30 \%$ & $29 \%$ & $8 \%$ & $14 \%$ & $29 \%$ & $17 \%$ & $9 \%$ & $11 \%$ & 76 \\
\hline Law and order & $24 \%$ & $20 \%$ & $20 \%$ & $20 \%$ & $20 \%$ & $16 \%$ & $8 \%$ & $28 \%$ & $12 \%$ & 25 \\
\hline TOTAL & 297 & 179 & 215 & 247 & 276 & 263 & 250 & 322 & 220 & 1533 \\
\hline
\end{tabular}

Note: Cells highlighted in grey indicate highest row percentage. Cells with bold contours ("thematic staircase") indicates where highest row percentages are expected. Row percentages do not add up to $100 \%$ due to MPs holding two committee seats simultaneously or switching committees during their parliamentary career.

those attributable to health policy in the Committee for Social Security and Health, etc. Based on this 'thematic' congruence between committees and policy domains of MP-group ties, we have drawn a 'thematic' staircase into Figure 5, corresponding to the cells with thick contours ascending from the bottom left to the top right corner of the figure. ${ }^{13}$ Some 'steps' are higher than others as more than one policy domain can be attributed to a particular committee. For instance, the 'Education, culture and sports' and 'Science and telecommunications' policy domains can both be attributed, at least theoretically, to the Committee for Science, Education and Culture. Finally, we excluded the 'Urban and regional development' category from our analysis since it does not represent the responsibility of one specific committee.

As can be seen in Figure 5, the grey cells, indicating the highest row percentages, follow our thematic staircase quite closely. In most cases, the highest percentage of ties attributable to a specific policy domain appears in the committee treating issues falling into this domain. For instance, 37\% of all 'Health' ties found within the National Council between 2000 and 2011 can be linked to the Committee for Social Security and Health $(\mathrm{CSSH})$. If these ties were spread equally across all nine committees, then this percentage should only amount to roughly $11 \%$. Twelve out of 15 cells within our thematic staircase display the highest row percentages, as expected. Only ties attributable to the 'Labor', 'Social' and 'Rights' policy domains run counter to our expectations. In fact, regarding 'Labor' ties, the highest row percentage is found in the Committee for Science, Education and Culture (CSEC). This is due to the fact that many IGs working on employment training (often professional associations), coded as 'Labor' IGs, hold ties to the members of this committee. With respect to 'Rights' ties, the Political Institutions Committee only comes in third place, behind the Committee for Social Security and Health (CSSH) as well as the Committee for Science, Education and Culture (CSEC). The strong concentration

\footnotetext{
${ }^{13}$ The matching between the policy domain and the committee has been established on the basis of the description of each committee's domain of competence (see the Parliamentary Services' website: http:// www.parlament.ch/e/organe-mitglieder/kommissionen/legislativkommissionen/Pages/default.aspx).
} 
of 'Rights' ties in the CSSH is due to Pro Infirmis, a group advocating for the rights of disabled persons. On the other hand, the rather high share of 'Rights' ties within the CSEC is due to the fact that more MPs spent time within this committee as compared to the Political Institutions Committee. A similar explanation holds in the case of 'Law and Order' ties, where we again find the largest share within the Science, Education and Culture Committee rather than the Legal Affairs Committee. With the exception of these few counter-intuitive observations, we observe a strong match between ties attributable to particular policy domain and the committee in charge of this policy domain.

This exploratory analysis hints at a certain congruence between committees and groups in terms of policy domains, in line with our fourth theoretical expectation. This might be both the consequence of MPs carrying previous ties into a committee or to groups recruiting MPs during their tenure of office. While the causality behind this phenomenon needs to be studied, groups seem to be able to forge themselves a strategic presence within parliamentary committees.

\section{Next research steps: biased access, policy influence and venue-shopping}

In this research note, we have presented an innovative dataset that opens the door for further longitudinal and cross-national research on interest groups, policy-making and parliamentary studies.

By focusing on the MP-group dyads present in the Swiss parliament during three legislative terms, we offered an overview of these ties over time, pointing out contrasts between types of groups, policy domains, political parties and parliamentary committees. While this research note provides a fresh look at interest groups in Parliament, the dataset on MP-group ties presented here can be mobilized to address more ambitious research questions. In this regard, we would like to highlight three concrete avenues for future research.

Much of the scholarly and political debates on interest groups, particularly when it comes to parliamentary lobbying, focus on the potential bias of interest representation and the differentiated access of groups to decision-makers. The conventional wisdom is that one should expect a higher mobilization, a higher institutional access and, eventually, a higher 'preference attainment' and policy success for business and professional groups than for other groups, namely public interest, institutional or identity groups (Lowery and Gray 2004; Schlozman, Verbaand, Brady 2012; for Switzerland, see Traber 2014). After all, these privileged groups have more resources (financial, staff, etc.) and a specific, material and short-term-oriented interest to promote. This stand can be traced back to the famous 'upper-class accent' in the pluralist heavenly chorus (Schattschneider 1975, pp. 34-35). Nevertheless, the seminal study by Baumgartner et al. (2009) on lobbying at the US Congress found no direct, positive and strong link between the level of resources of an interest group and its policy success. Turning to Switzerland: what are the policy consequences of yodeling with an 'upper-class accent' in the Bundeshaus corridors?

The first set of research questions would consequently investigate biases in the mobilization and access of interest groups to Parliament. What determines who is 'in' and who is 'out' (Fraussen and Beyers 2016)? Which factors (e.g. resources, membership, scale of organization, policy portfolio, etc.) affect this? In order to assess the presence and the extent of biased representation, we require data on the entire population of interest groups in Switzerland as a benchmark. Comparing the entire population of groups and those with privileged access would allow the identification of biases between political mobilization and institutional access. To the best of our knowledge, only one study has attempted so 
far to systematically capture the entire interest groups population in Switzerland. Jentges and colleagues (2013) created such an inventory of groups for 2010 by combining various sources, among which the Publicus and the verbaende.ch websites. In total, Jentges et al. (2013: 34-35) identified 2'475 organizations that were eventually contacted by means of an online survey. Around one third of them took part in the survey and delivered key information about their organization (founding year, policy domain, number of full-time staff, etc.) and communication strategies towards members, politicians, media, other groups and citizens. The next logical step will then be to cross our respective datasets. More ambitious studies may turn to the evolution over time. Do changes in the interest group population, as for instance a strong increase in public interest groups, affect the representation in political arenas? (see Binderkrantz et al. (2014) for an application of this research design in Denmark 1975-2010).

Access to MPs is a precondition for groups' influence and policy preference attainment. A second set of research questions may focus on the extent to which ties with groups influence MPs' behavior. In Switzerland, Lüthi, Meyer and Hirter (1991) and Schwarz and Linder (2007) have investigated if MPs with similar interest affiliations vote in a cohesive way. These pioneer studies showed that MPs having ties with economic interest groups display a more cohesive voting behavior than MPs affiliated to public interest groups focusing on environmental, humanitarian or social issues. Two recent studies have further assessed to what extent interest affiliations affect parliamentary behavior. On one hand, Bailer (2011), focusing on parliamentary questions during 2003-2007, tested the following hypothesis: "The greater the interest in representing interest groups, the more often parliamentarians ask oral parliamentary questions' (Bailer 2011: 304). As we did, she captured the number of ties between MPs and groups by means of the official register of interests. She found that, contrary to the theoretical expectation, the number of mandates is related to a decrease in the number of parliamentary questions. MPs with direct ties with interest groups seem not to exploit this parliamentary instrument to control the governmental policies and/or to put their own policy issues on the agenda.

On the other hand, Giger and Klüver (2016) investigated the extent to which parliamentary voting is influenced by MPs' electoral constituencies and interest affiliations. MPs' defections from their constituencies may be related to linkages with groups displaying conflicting policy positions. In particular, the authors expect this for close relationships between MPs and 'sectional' groups (i.e. business or professional groups): “The larger the number of sectional groups that support an MP, the higher the probability that the MP defects from her constituents" (Giger and Klüver, 2016: 193). Two thirds of the MPs voting on 118 legislative proposals do not defect from their constituents and vote in accordance with their voters' preferences ${ }^{14}$. At the same time, a high number of ties with sectional groups increases the probability that MPs defect. By contrast, as the number of affiliations with 'cause' groups (i.e. public interest groups) goes up, the probability that MPs deviate from the preferences of their respective constituency decreases.

These two recent studies are complementary since they focus on different aspects of the parliamentary game, namely parliamentary interventions and legislative votes. They are pioneer contributions to assessing the conditions under which interest groups influence

\footnotetext{
${ }^{14}$ This finding must be considered with caution. The authors operationalize MPs' constituencies as the aggregate electorate from the respective MPs' cantons, without taking into consideration whether citizens voted or not for the MP's party. This is problematic, as we have seen that (many) interest groups target specific political parties and that MPs with ties to specific types of interest groups vote in a cohesive way.
} 
both the control and law-making functions of the Parliament. Despite the fact that the two studies rely on the same measurement of interest groups presence in Parliament (i.e. number of interest affiliations), many pressing questions cannot be easily addressed (i.e. no distinction between types of interest groups in Bailer (2011), and lack of policy domains and disputable proxy for the MPs constituency in Giger and Klüver (2016)). In light of this, our longitudinal dataset based on comparative research projects seems a promising step towards cumulative research. For instance, parliamentary interventions (questions, motions, postulates and parliamentary initiatives) and legislative outputs have already been classified according to the CAP policy domains. One could thus investigate the extent to which MP-group ties in a specific policy domain explain parliamentary behavior (e.g. agenda-setting, co-sponsorship, voting) in that policy domain and time-periods.

Third, upcoming studies on the mobilization, access and policy influence of interest groups should move beyond MP-group dyads, and consider the entire set of institutional venues activated during policy-making processes (Holyoke 2003). Many empirical studies ask interest groups to self-assess their typical patterns of advocacy strategy in policy decontextualized surveys. Unsurprisingly, interest groups generally declare using very diverse actions repertoires in many institutional venues. However, the strategies of interest groups need to be linked to specific policy-making processes (Baumgartner 2007: 487; Baumgartner and Leech 1998: 174; Beyers 2008: 1206-1207; Halpin and Binderkrantz 2011: 207; Hojnacki et al., 2012) in order to capture the real engagements of interest groups across institutional venues (e.g. pre-parliamentary consultations, parliamentary committees, ex-post referendum campaigns, etc.). Such an approach, which was already applied to the most salient decision-making processes in the 1970s (Kriesi 1980) and in the 2000s (Sciarini 2014) in Switzerland, allows identifying multi-venue and venue-specialized groups. It should now be compared to other empirical studies investigating policy advocacy by interest groups along an entire policy-making process (see: Jourdain et al. (forthcoming) and Varone et. al. (2016) for similar case studies in California).

Since the pre-parliamentary administrative phase has lost importance in relation to the parliamentary venue, traditional corporatist actors (i.e. business groups and unions) have lost influence (Sciarini 2014). By contrast, public interest groups might have become more present and thus, influential in policy processes. To systematically test this hypothesis, it would make sense to compare, for all legislative processes, if and to what extent different (types of) interest groups participate in the administrative pre-parliamentary consultations, parliamentary debates and votes (see Pedersen et al. (2014) for a similar research design in Denmark). Such a research strategy would help us to assess whether Switzerland has moved towards a new parliamentary pluralism; or, on the contrary, that some interest groups still cumulate a privileged access to both the administration and the Parliament.

\section{References}

Armingeon, K. (2011). A prematurely announced death? Swiss corporatism in comparative perspective. In Trampusch, C. and A. Mach (eds.), Switzerland in Europe: Continuity and change in the Swiss political economy. New York: Routledge (165-185).

Bailer, S. (2011). People's Voice or Information Pool? The Role of, and Reasons for, Parliamentary Questions in the Swiss Parliament. The Journal of Legislative Studies 11(3): 302-314.

Baumgartner, F. (2007). EU Lobbying: A View from the US. Journal of European Public Policy 14(3): 482-488. 
Baumgartner, F., J. Berry, M. Hojnacki, D. Kimball and B. Leech (2009). Lobbying and Policy Change: Who wins, who loses, and why. Chicago and London: University of Chicago Press.

Baumgartner, F. and B. Leech (1998). Basic interests: The Importance of Groups in Politics and in Political Science. Princeton: Princeton University Press.

Bellini, C. (2014, 01.05.2014). Lobbys, comment ils font la loi sur les médicaments. L'Hebdo.

Beyers, J. (2008). Policy issues, organisation format and the political strategies of interest organisations. West European Politics 31(6): 1188-1211.

Beyers, J., R. Eising and W. Maloney (2008). Researching Interest Group Politics in Europe and Elsewhere: Much We Study, Little We Know? West European Politics 31(6): 1103-1128.

Binderkrantz, A., H. Fisker and H. Pedersen (2014). Moderate spill-over in the influence production process. How changes in interest group populations affect representation in political arenas. Aarhus University.

Binderkrantz, A., P. Munk Christiansen and H. Pedersen (2015). Interest Group Access to the Bureaucracy, Parliament, and the Media. Governance 28(1): 95-112.

Buchs, J.-P. (2014, 25.06.2014). Le Parlement refuse toute transparence. Bilan: 34-35.

Bruderer, P. (2005). Lobbyisten im Ratssaal. In Baeriwyl, O. (ed.). Lobbying in der Schweiz. Villarssur-Glâne: Verl. mediadata (177-195).

Commission des institutions politiques du Conseil national. (2001). Initiative parlementaire. Loi sur le Parlement (LParl). Rapport de la Commission des institutions politiques du Conseil national (01.401).

David, T., S. Ginalski, A. Mach and F. Rebmann (2010). Networks of Coordination: Swiss Business Associations as an Intermediary between Business, Politics and Administration during the 20th Century. Business and Politics 11(4).

Fraussen, B. and J. Beyers (2016). Who's In and Who's Out? Explaining Access to Policymakers in Belgium. Acta Politica 51(2): 214-236.

Giger, N. and H. Klüver (2016). Voting against your constituents? How lobbying affects representation. American Journal of Political Science 60(1): 190-205.

Green-Pedersen, C. and S. Walgrave (2014). Agenda Setting, Policies, and Political Systems: A Comparative Approach. Chicago: Chicago University Press.

Halpin, D. and A. Binderkrantz (2011). Explaining breadth of political engagement: patterns of interest group mobilization in public policy. Journal of European Public Policy 18(2): 201219.

Häusermann, S., A. Mach and Y. Papadopoulos (2004). From Corporatism to Partisan Politics: Social Policy Making under Strain in Switzerland. Swiss Political Science Review 10(2): 33-59.

Hojnacki, M., D. Kimball, F. Baumgartner, J. Berry and B. Leech (2012). Studying Organizational Advocacy and Influence: Reexamining Interest Group Research. Annual Review of Political Science 15(1): 379-399.

Holyoke, T. (2003). Choosing Battlegrounds: Interest Groups Lobbying across Multiple Venues. Political Research Quarterly 56(3): 325-336.

Jegher, A. (1999). Bundesversammlung und Gesetzgebung. Berne: Haupt.

Jegher, A. and P. Lanfranchi (1996). Der Einfluss von National- und Ständerat auf den Gesetzgebungsprozess. Eine Analyse quantitativer und qualitativer Aspekte der parlamentarischen Gesetzgebungstätigkeit in der 44. Legislaturperiode (1991-95). Berne: Institut für Politikwissenschaft, University of Berne.

Jegher, A. and W Linder (1998). Schweizerische Bundesversammlung: eine aktive Gesetzgebungsorgan. Eine empirische Untersuchung des Gesetzgebungsprozesses in den Jahren 1995-97. Berne: Institut für Politikwissenschaft, University of Berne. 
Jentges, E., M. Brändli, P. Donges and O. Jarren (2013). Communication of political interest groups in Switzerland: Adressees, channels and instruments. Studies in Communication Sciences 13(1): 33-40.

Jordan, G., D. Halpin and W. Maloney (2004). Defining Interests: Disambiguation and the Need for New Distinctions? British Journal of Politics and International Relations 6(2): 1-18.

Jourdain, C., S. Hug and F. Varone (forthcoming). Interest Group Mobilization Across Venues: A Policy Contextualized Approach. State Politics \& Policy Quarterly.

Katzenstein, P. (1985). Small States in World Markets. Ithaca: Cornell University Press.

Kohli, A. (2014, 04.03). Lobbying durch die Hintertür. Neue Zürcher Zeitung.

Kriesi, H. (1980). Entscheidungsstrukturen und Entscheidungsprozesse in der Schweizer Politik. Frankfurt and New York: Campus.

- (2001). The Federal Parliament: The Limits of Institutional Reform. In Lane, J-E. (ed.), The Swiss Labyrinth. Institutions, Outcomes and Redesign. London: Frank Cass.

Lowery, D. and V. Gray (2004). Bias in the heavenly chorus: Interests in society and before government. Journal of Theoretical Politics 16(1): 5-30.

Lowery, D., , Halpin and V. Gray (2015). The Organization Ecology of Interest Communities: Assessment and Agenda. Basingstoke: Palgrave Macmillan.

Lüthi, R. (1997). Die Legislativkommissionnen der schweizerischen Bundesversammlung. Institutionelle Veränderungen und das Verhalten von Parlamentsmitgliedern. Berne: Haupt.

Lüthi, R., L. Meyer and H. Hirter(1991). Fraktionsdisziplin und die Vertretung von Partikulärinteressen im Nationalrat. In Parlamentsdienste (ed.), Das Parlament - 'Oberste Gewalt des Bundes'? Festschrift der Bundesversammlung zur 700-Jahr-Feier der Eidgenossenschaft. Berne: Haupt (53-71).

Mach, A. (2014). Associations d'intérêt. In Knoepfel, P., Y. Papadopoulos, P. Sciarini, A. Vatter and S. Häusermann (eds.), Manuel de la politique suisse. Zurich: Verlag Neue Zürcher Zeitung (413-434).

- (2015).Groupes d'intérêt et pouvoir politique. Lausanne: PPUR (Le savoir suisse).

Nicolussi, R. (2014a, 04.03.2014). Der gross Badge-Basar. Neue Zürcher Zeitung.

— (2014b, 04.03.2014). Die wahren Interessen der Lobbyisten. Neue Zürcher Zeitung.

Péclat, M. and S. Puddu (2015). Links of interest of Swiss MPs: a comprehensive dataset. IRENE Working paper No. 15-04.

Pedersen, H., P. Munk Christiansen and A. Binderkrantz (2014). Lobbying Across Arenas: Interest Group Involvement in the Legislative process in Denmark. Legislative Studies Quarterly 39(2): $199-225$.

Pilotti, A. (2012). Les parlementaires suisses entre démocratisation et professionnalisation (1910-2010). Biographie collective des élus fédéraux et réformes du Parlement fédéral. University of Lausanne, Lausanne.

Puddu, S. and M. Péclat (2015). Dangerous liaisons: Interest groups and politicians' votes. A Swiss perspective. IRENE Working paper No. 15-09.

Rommetvedt, H., G. Thesen, P. Munk Christiansen and A. Norgaard (2012). Coping With Corporatism in Decline and the Revival of Parliament: Interest Group Lobbyism in Denmark and Norway, 1980-2005. Comparative Political Studies 46(4): 457-485.

Schattschneider, E. (1975). The Semisovereign People: A Realist's View of Democracy in America. New York: Thomson Learning.

Schlozman, K., S. Verba and H. Brady (2012). The Unheavenly chorus. Unequal Political Voice and the Broken Promise of American Democracy. Princeton: Princeton University Press.

Schwarz, D., A. Bächtiger and G. Lutz (2011). Agenda-setting power of the government in a separation-of-powers framework The role of government in legislative agenda setting. London: Routledge. 
Schwarz, D. and W. Linder (2007). Fraktionsgeschlossenheit im schweizerischen Nationalrat 19962005: Studie im Auftrag der Parlamentsdienste der schweizerischen Bundesversammlung: Institut für Politikwissenschaft, University of Berne.

Sciarini, P. (2014). Eppure si muove: the changing nature of the Swiss consensus democracy. Journal of European Public Policy 21(1): 116-132.

Sciarini, P., M. Fischer and D. Traber (2015), (eds.). Political Decision-Making in Switzerland. The Consensus Model under Pressure. Houndmills: Palgrave Macmillan.

Varone, F., I. Engeli, P. Sciarini and R. Gava (2014). Agenda-Setting and Direct Democracy: The Rise of the Swiss People's Party. In Green-Pedersen, C. and S. Walgrave (eds.), Agenda setting, policies, and political systems: a comparative approach. Chicago: University of Chicago Press (105122).

Varone, F., K. Ingold and C. Jourdain (2016). Defending the Status Quo across Venues and Coalitions: Evidence from California Interest Groups. Journal of Public Policy (on-line, doi:10.1017/S0143814X16000179).

Zaugg, J. (2011, 21.09.2011). Les petits oublis des parlementaires. L'Hebdo.

Zehnder, E. (1988).Die Gesetzüberprüfung durch die Schweizerische Bundesversammlung. Untersuchung der parlamentarischen Veränderungen von Vorlagen des Bundesrates in der Legislaturperiode 1971 bis 1975. St. Gallen: University of St. Gallen.

Roy Gava is Lecturer and Post-Doctoral Researcher at the Department of Political Science and International Relations, University of Geneva. His research interests include comparative public policy, financial regulation and legislative production. Address for correspondence: Department of Political Science and International Relations, University of Geneva, Uni Mail, Bd. du Pont d'Arve 40, 1211 Geneva 4, Switzerland. Email: roy.gava@unige.ch

Frédéric Varone is professor at the Department of Political Science and International Relations, University of Geneva. His research interest include comparative public policy and the advocacy strategies of interest groups. Email: frederic.varone@unige.ch

André Mach is Associate Professor at the Institute of Political, Historical and International Studies, University of Lausanne. His research interests include Swiss politics, sociology of elites and the study of interest groups. Email: andre.mach@unil.ch

Steven Eichenberger is a Ph.D. student at the Institute of Political, Historical and International Studies, University of Lausanne. His research interests include interest group strategies, comparative public policy and legislative organization. Email: steven.eichenberger@unil.ch

Julien Christe is a recent graduate of the Master of Arts in Political Science at the University of Geneva. His interests include interest groups and legislative processes. Email: j.christe@bluewin.ch

Corinne Chao-Blanco is a recent graduate of the Master in Public Management, University of Geneva. Email: corinne.chaoblanco@gmail.com 